\title{
The Tannenberg Myth in History and Literature, 1914-1945
}

Major wars and battles play an important role in national thought and collective memory. ${ }^{1}$ From the Siege of Troy and the Battle of the Teutoburg Forest to Agincourt, Waterloo, and D-Day, military campaigns have captured the imagination of subsequent generations, literary circles, artists, and, more recently, filmmakers. ${ }^{2}$ This does not apply to victorious operations only: the tragedy of defeat and the self-denying heroism of the defenders against overwhelming forces have fascinated as well - and quite possibly even more. ${ }^{3}$ Starting with Herodotus, the last stand of the Spartans at the Battle of Thermopylae has been dramatized by numerous eminent writers and poets, including Lord Byron, A.E. Housman, and Heinrich Böll. Lord Tennyson immortalised the ill-fated Battle of Balaclava in his 'Charge of the Light Brigade', while the Battles of the Alamo and of Dien Bien Phu were made into films. In some cases, these works conveyed critical and pacifist messages: Arnold Zweig's novel Erziehung vor Verdun and the Vietnam War film Hamburger Hill are typical examples. With regard to the First World War, it also seems that failed campaigns have had a more powerful and enduring grip on the public imagination and national consciousness: Gallipoli, the Somme, and Caporetto are some of the most important lieux de mémoire in Australia, Britain, and Italy. In Canada, Vimy Ridge and Passchendaele are widely remembered - tactical victories, it is true, but like the French defensive success at Verdun achieved at a very high cost. While these battles have more recently come to exemplify the futility of war, originally they were often utilised to provide glorious examples of patriotism, loyalty, and the readiness to make sacrifices in the name of the nation. ${ }^{4}$ Arguably, a similar tendency to favour narratives of tragic loss and heroic resistance over stories of complete and utter triumph can be detected in the case of the German battle myths of the First World War. Stefan Goebel has described the Battle of Tannenberg in late August 1914 as 'the most powerful German myth of the war', 
but it seems that in the long term the victory in East Prussia never reached the same popularity and breadth of appeal as Langemarck (November 1914) and Verdun (February December 1916) on the Western front. ${ }^{5}$ It has certainly attracted much less scholarly attention. ${ }^{6}$ Indeed, most studies on the myth and legacy of Tannenberg focus on the first Battle of Tannenberg in 1410 which resulted in the momentous defeat of the Teutonic Knights at the hands of Polish-Lithuanian forces. ${ }^{7}$ Scholarly books on Paul von Hindenburg refer to the events in August 1914 as a major turning point in his life and the beginning of his rise to popularity, but while the Hindenburg cult and the Tannenberg myth are closely related, they are by no means identical. ${ }^{8}$ And although cultural historians and scholars of art history have written extensively about the impressive Tannenberg memorial that was built in the late 1920s, we are still lacking a comprehensive and thoroughly researched analysis of the role of the battle in German collective memory, its narrative articulation, and literary and mythical resonance.

The Battle of Tannenberg (26 - 30 August 1914) was a pivotal moment in the initial stages of the First World War. According to the Schlieffen Plan, the German supreme command had committed its main military forces against Belgium and France. Anticipating a slow mobilisation of Tsarist troops and resources, it merely deployed one Army to protect East Prussia against a Russian invasion. Commanded by Maximilian von Prittzwitz, the German 8th Army comprised a considerable number of reservist units and was massively outnumbered by the Russian 1st Army (Neman Army), led by Paul von Rennenkampf and advancing from the East, and the Russian 2nd Army (Narew Army) under the command of Alexander Samsonov, which was attacking from the South-East. Following initial encounters 
at Stallupönen and Gumbinnen (17 - 20 August 1914) and fearing an encirclement by the Tsarist forces, Prittwitz ordered a general retreat to the Vistula river. ${ }^{9}$ On 22 August, Prittwitz and his chief of staff Georg von Waldersee were replaced by Paul von Hindenburg, who had retired in 1911 after an unremarkable military career, and the energetic Erich Ludendorff, who had just made his name as the victor of Liège. The mass of the German 8th Army now turned south against Samsonov's troops (while Rennenkampf was advancing slowly towards Königsberg). Hampered by poor communication, insufficient military intelligence, logistical problems, as well as a lack of training and heavy artillery, the Narew Army suffered a devastating defeat, resulting in c. 50,000 casualties and the additional loss of 90,000 prisoners (at the cost of about 10,000 German soldiers). One of the few non-attritional victories of the war by any of the major belligerents, Tannenberg is often considered a prime example of a successful encirclement campaign, comparable to the Battle of Nations in 1813 and the German operations near Metz and Sedan in 1870. The extent to which it differed from the Battles of the Somme or Verdun in 1916, for example, is obvious: rather than challenge established notions of warfare, the campaign seemed to confirm the pre-war belief in decisive breakthroughs and the cult of the offensive. Lasting a mere five days or so, it was also much shorter than many other major battles of the First World War, ultimately leading to the liberation of German soil from enemy forces within a few months (Battles of the Masurian Lakes). ${ }^{10}$

Interestingly, the first German reports about the August encounter spoke of 'a clash between Gilgenburg and Ortelsburg' or a 'victory near Allenstein', but it quickly became known as the 'Battle of Tannenberg', referring to a small village several kilometres further to the West which carried much symbolic meaning and emotional value in German national history. ${ }^{11}$ It was here that the Teutonic Knights had been defeated by a Polish-Lithuanian army in July 1410, and many Poles increasingly identified with and celebrated the event (here 
known as the Battle of Grunwald) as an example of past glory, drawing much inspiration from it for their struggle for independence. ${ }^{12}$ In the opinion of many German intellectuals and publicists, on the other hand, this defeat had put an end to German eastward expansion and severely undermined the standing of the medieval order and alleged predecessor of the Prussian state. ${ }^{13}$ As Hindenburg later wrote in his memoirs: 'Tannenberg! An event that is still with us after more than five hundred years, signifying Slav triumphalism and a painful memory of the German knightly order.' ${ }^{14}$ Against this background, the victory of 1914 appeared as a revenge for that previous national humiliation and as a final triumph over the Slavs. In accordance with the widely-held notion of an eternal struggle between Germandom and Slavdom, at least within right-wing and nationalist circles, the difference between the original Polish-Lithuanian forces and the troops of the Russian Tsar was ignored. Indeed, the ostensible link between the two battles was quickly taken up and popularised by numerous publicists and writers. 'In a remarkable and most momentous manner', the East Prussian weekly Königsberger Woche wrote in September 1914, 'this wonderful victory ties in with that other Battle of Tannenberg half a millennium ago when the Slavs for the first time in history succeeded in defeating our Volk and to shatter the bulwark of the knightly order in the East. The heroic deeds of German men on the blood-soaked ground near Tannenberg appears as a late revenge and triumph over the impudent hubris of Slav claims to power.' ${ }^{15}$ At around the same time, the periodical started to invite contributions from amateur poets, who often referred back to the Teutonic Knights, too, juxtaposing the two battles in the context of the ancient Slavo-German struggle for supremacy in the East:

\section{At Tannenberg}

At Tannenberg in forest and marsh, A proud heroic tale died away: Jagiello the Masurian

Defeated the German lords there,

The order's luck and purpose vanished,

The commanders succumbed.
At Tannenberg in forest and marsh, A proud heroic tale began to appear: The Landwehr from East Prussia Fought three days and nights, And with streams of blood it quenched The presumption of the Russians. 
And the lands of the Balts and Latvians

Fell into the hands of the Slavs,

The German sword in the East

Seemed to rust.
The German blade was far from blunt

And chased the enemy into sea and swamp,

Defeating it heavily.

We have redeemed the pledge:

Hail lands of the Balts and Latvians,

The Germans are back. ${ }^{16}$

Most of these Tannenberg poems, published all over Germany in newspapers and

anthologies, were of a rather dubious literary quality and demonstrated an aggressive and

triumphant tone. Like much of German Weltkriegslyrik, they lacked imagination and

originality, often following the simple patterns and established motifs of previous war poetry

from the Napoleonic period up to the wars of unification. ${ }^{17}$ Tannenberg poems usually

conveyed a romantic image of the war, referring back to the Teutonic Order, highlighting

East Prussian suffering and heroic endurance against the Russian atrocities, and depicting the

enemy troops as primitive and barbarian invaders, often employing dehumanising language

and speaking of a ravaging and almost unstoppable 'Moscovite flood', 'swarm of

grasshoppers', and 'Russian beasts of prey'. ${ }^{18}$ In a poem focusing on the misery of the local population, the young East Prussian writer Fritz Kudnig, for example, portrayed the Russians as 'predators': 'An ogre with striking flanks, / spitting fire in boundless rage, / and its devilish paws / are oozing bright red human blood. ${ }^{19}$ It is estimated that up to 800,000 East Prussians

fled their homes and that 1,500 civilians were killed during the Russian invasion in August and September $1914 .^{20}$ The atrocities against innocent women and children, the destruction of hundreds of East Prussian villages, and the plight of the refugees were widely reported in the German press and led to numerous expressions of solidarity and support. ${ }^{21}$ A particularly ferocious poem, first published in the liberal Frankfurter Zeitung and frequently reprinted, was penned by the renowned theatre critic and journalist Alfred Kerr, who had become notorious for his jingoistic and bellicose war poetry and here depicted the Russians as 'dogs' that needed to be 'flogged' and kicked back into Russia: 


\section{East Prussia}

Has your land, Immanuel Kant,

Been overrun by Scythians?

Stinking and brawly

trudge dull steppe swarms.

Dogs broke into the house -

Flog them out! [...]

They must not prevail -

Flog them until their skin falls in strips,

Scum of the Tsar, barbarian scum -

Flog them away! Flog them away!22

The notion of the Tsarist troops as dirty, barbarian, and animal-like contributed to the

widespread popularity of the 'sea legend', according to which thousands of Russians in their panic and confusion during the Battle of Tannenberg and the subsequent Masurian Lakes Campaign had drowned in the local lakes and swamps. ${ }^{23}$ In many cases, this was trivialized and satirized in poems, but also in caricatures and propaganda postcards as taking a muchneeded 'bath', quasi a civilizing act by the culturally and morally superior German troops. Another popular anecdote had the retired Hindenburg tour the future battlefield from his nearby estate at Neudeck with an artillery piece, thus demonstrating the general's ostensible foresight and highlighting his personal connection with East Prussia. ${ }^{24}$

Tannenberg thus appeared in a quixotic and almost archaic light, like a tale from a bygone age that clearly differed from the modern but static and costly warfare on the Western front. Ultimately, it was argued, the urdeutsch territory had been rescued by the strategic brilliance and leadership of Paul von Hindenburg who embodied the ancient Prusso-German sense of duty, discipline, and loyalty. ${ }^{25}$ As the Süddeutsche Monatshefte put it in July 1915, the Germans had witnessed a number of 'glorious feats of arms' since the outbreak of war: 'Liège and Metz, Santa Maria and Antwerp, Soissons and Tarnów, Przemyśl and Stryi - and we confidently anticipate many more. But none will be received more cheerfully than the news from Masuria, from Tannenberg and Insterburg: because this campaign restored our threatened homeland.' Hindenburg's masterful command would ensure many similar 
successes and bring ultimate victory in this war. ${ }^{26}$ Even Social Democrats celebrated the victory at Tannenberg as a 'redeeming act for the whole of Germany' and described Hindenburg as the 'embodiment of German resilience', a popular and formidable 'symbol of power and calm'. ${ }^{27}$ In a hugely popular account of the battle, going through at least twentyfour editions within less than two years, one author even went as far as to argue that 'the bravery and monumental efforts' of the common soldiers were commendable, but that the 'unparalleled triumph' was 'solely' due to the brilliant strategy of the 'greatest commander ever' ${ }^{28}$ At school, teachers discussed the battle in class, especially in History, Geography, and Mathematics, and presented the saviour of East Prussia as a 'model of calm and sober calculation', of 'determined and successful action' ${ }^{29}$ Amateur poets and established writers, too, praised the general as an intelligent but down-to-earth man of the people and likened him to heroic figures of the past, mythical and real, such as Siegfried, Arminius, Blücher, and Bismarck. ${ }^{30}$ The Bavarian popular writer and war correspondent Ludwig Ganghofer, for instance, after his first encounter with Hindenburg described the general as an unwavering, hard-working, and awe-inspiring character: 'Ten o'clock. Suddenly all officers rise. The door opens and the Field Marshal enters, dressed in a comfortable litevka, serious, nodding a silent greeting. He left his work late and it is obvious that his mind is still preoccupied, but in his gestures and iron face [...] there is no trace of exhaustion; rather, the marshal appears as someone who was outside to seek some refreshment, like a hunter who enjoyed an evening walk. [...] Suddenly all those images of destruction from East Prussia and the Masurian Lakes flash before my eyes. And against this background I count myself lucky and blessed to meet the German military leader who managed to fend off this devastating threat from our homeland. ${ }^{31}$ Countless poems acclaimed the general as a national guardian, a symbol of German invincibility and God's love for the nation, as 'Russentod' and 'Russenschreck'. ${ }^{32}$ Even Stefan George, who had refrained from participating in the spiritual mobilisation of the 
nation and the war of words, in a rare and rather untypical poem of 1917 celebrated the arrival of 'the forgotten and plain old man' and his heroic rescue of the 'Reich'. ${ }^{33}$

Although war poetry remained the predominant medium for the glorification of Tannenberg, there were also various other literary works, including novels, short stories, several theatre plays, and even a thirty-page rhymed epic. They typically depicted East Prussian suffering and defiance against Russian brutality and barbarism - the author of the battle epic spoke of 'slavish wolves', bloodthirsty vermin', and 'ghastly horsemen of the apocalypse' -, the momentous intervention and ingenious decision-making of Hindenburg, and the total and disastrous defeat of the Tsarist troops, culminating in the liberation of East Prussian soil and the restoration or rebuilding of German towns and 'civilization' ${ }^{34}$ These works were composed by amateur and lesser-known writers, such as Josef Karlmann Brechenmacher, a teacher and etymologist from the Black Forest region, who wrote an account of the 'gigantic battle [Riesenschlacht]' of Tannenberg for the German youth. Wilhelm Hermann Schultze (also known as Wilhelm Arminius), a teacher and prolific author of books for children and young readers, published two works about Tannenberg, including a spy story. Other examples include the Bavarian journalist and popular writer Viktor Martin Otto Denk and Adolf Vogeler, a teacher from Hildesheim whose Tannenberg play was staged at the local theatre in October $1917 .{ }^{35}$

However, the battle soon seems to have faded from German public discourse. ${ }^{36}$ Tannenberg's appeal among broad sections of the German population during the early stages of the war had stemmed from several factors. It underlined the notion of a German defensive war against brutal invaders: a victorious last stand of self-sacrificing troops against all odds, saving not just a province but arguably the whole German East against the Russian threat at the very moment when the German successful advance in the West was stopped at the Battle of the Marne. The victory was said to carry world-historical signficance, reversing the 
national humiliation of 1410 and proving German superiority over the Slavs, achieved by the military ingenuity of a new national hero. Indeed, following further successes in the European East and in view of the stalemate and attritional fighting on the Western front, Hindenburg came to be seen as a guarantor of victory par excellence, surpassing even the Kaiser's popularity. ${ }^{37}$ In the words of Anna von der Goltz: 'Many Germans wanted to believe in a traditional war hero, symbolizing past glory, providing fatherly stability, embodying the newly-found sense of political unity, and upholding the belief in eventual military victory. ${ }^{38}$ Appointed to succeed Erich von Falkenhayn in August 1916, exactly two years after Tannenberg, Hindenburg and Ludendorff soon turned the German supreme command into a 'silent dictatorship', instrumentalising the Field Marshal's reputation for the total mobilisation of the German home front and the continued struggle for a peace of victory. ${ }^{39}$ The heroic campaign of August 1914, in contrast, became an empty catchword, usually invoked in connection with the general as the 'victor of Tannenberg'. For most Germans, at least those outside of East Prussia, it clearly did not seem particularly relevant any longer. ${ }^{40}$

\footnotetext{
After 1918, the Tannenberg myth experienced a renaissance, although it became monopolised by the national Right which emphasised the loss of territory in the East as a consequence of the Treaty of Versailles - even a part of the battlefield had become Polish now - and the 'long-standing struggle' between Germandom and Slavdom rather than the actual events of August 1914. In his memoirs, published in 1919 against the background of the Paris peace negotiations and border disputes, Erich Ludendorff stressed the symbolic value and significance of Tannenberg for the present, warning against a repetition of the shameful defeat of 1410: 'Will the German allow once again that the Lithuanian and in particular the
} 
Pole capitalise on our helplessness and violate us? Shall centuries-old German culture be lost forever? ... This soil was not saved just to let it it come under foreign yoke again. Heaven protect us from such humiliation. ${ }^{41}$ General Hermann von François, who had commanded a Corps of the Eighth Army during the battle, wrote similarly in 1922: 'The Tannenberg of 1914 is a victory of German being over Slavdom, a magnificent battle of revenge [for 1410] that is almost unique in world history. And yet: the Slavic storm flood has invaded Prussia again and Poles are subjugating Germans. ${ }^{42}$ Such rhetoric, which resumed and amplified anti-Polish sentiments from the pre-war period and integrated the Russian invasion of 1914 into the notion of a perpetual Slav threat to the German nation, was characteristic for many annual Tannenberg celebrations in towns and villages, especially in the eastern provinces.

The battle played an important role during the acrimonious plebiscite campaigns in Warmia and Masuaria (July 1920), conjured up to stress the region's German character and its historic mission as a bulwark against the Slavs. The speeches at the inauguration of the Tannenberg memorial in September 1927 promoted a similar agenda. The foundation stone had been laid near Hohenstein three years before, on the tenth anniversary of the battle. Privately funded by Prussian-conservative and monarchistic groups, this largest German war memorial looked like a modern version of a Germanic medieval fortress: 'The towers connoted prehistoric stone circles; the fortress-like structure reminded observers of the castles of the Teutonic Order or the Castel del Monte in Apulia, southern Italy, built by Frederick II of Hohenstaufen in 1240; and the simple but elegant design revealed the influences of expressionism, functionalism and Art Deco. ${ }^{43}$ The memorial contained the remains of twenty unknown soldiers from the Eastern front and was clearly intended as a symbolic bastion or outpost of German culture and independence in encircled territory. ${ }^{44}$ Wearing the uniform of an Imperial German General Field Marshal, Reich President Hindenburg used the opportunity of the unveiling ceremony, which was attended by c. 100,000 people, to reject the 'war guilt lie' 
by highlighting the German defensive effort against the Russian invaders and their allies. The German people, Hindenburg declared, had fought 'against a world full of enemies': 'It was not envy, hatred, or the will to conquer that made us spring to arms. ... Pure in heart we set off to the defense of the fatherland'. He also evoked the 'spirit of 1914', thus emphasising the need for national unity and reconciliation: 'In the countless tombs, which are symbols of German heroism, rest men from all parties. Back then, they were united in their love of and loyalty to the common fatherland. May domestic quarrel thus smash into pieces in front of this memorial; may it be a place where all shake hands with everyone who is inspired by the love to the fatherland and for whom German honour stands above everything. ${ }^{45}$ Key parts of the speech were later engraved on a plaque within the memorial. ${ }^{46}$ Despite the attendance of Chancellor Wilhelm Marx from the Centre Party and various cabinet ministers, the absence of democratic politicians, high-ranking Prussian state officials (the government was led by the SPD), and representatives from republican and Jewish veteran associations was conspicuous and underlined the national-conservative nature of the event. In subsequent years, Tannenberg remained a right-wing lieu de mémoire and icon of German revisionism. The memorial was hailed as 'a national place of pilgrimage in the German East', 'a landmark and symbol of German ingenious leadership and the bravery and strength of the German people'. As this völkisch author of one of the key publications on the memorial concluded: 'May this monument always remind us of those we have lost. ... A lunatic peace has separated this echt-deutsche, robust province from the motherland and handed over West Prussia, Danzig, and Posen to the Poles. Always remember and never ever forget: We have to have all this back and our German brothers in Austria as well. ${ }^{97}$

Hindenburg's wartime popularity had survived military defeat and political revolution remarkably intact, and greatly contributed to his 1925 election as President of the Weimar Republic. In line with the powerful stab-in-the-back legend, the national Right blamed the 
'November criminals' for the lost war. Democratic political circles, on the other hand, held the Kaiser and Ludendorff responsible for the protracted fighting and excessive war aims, although many workers also regarded Hindenburg with hostility and suspicion. While the latter largely stayed out of politics in the post-war period, Ludendorff made no secret of his anti-democratic views. Sharing the revolutionary activism of the new nationalists, he participated in both the Kapp Putsch of 1920 and Adolf Hitler's failed coup attempt three years later. In an attempt to dissociate the Tannenberg myth from Hindenburg and the conservative-traditionalist ideals of the Wilhelmine regime, Ludendorff in September 1925 founded the so-called Tannenberg-Bund, an umbrella group of völkisch anti-Semites, militarists, and advocates of a 'Germanic religious community'. As he argued in his Tannenberg monograph, the battle had stood at the beginning of 'German racial awakening and German recognition of God'. In Ludendorff's opinion, 'the same secret enemies, those suprastate forces whose plans I defeated at Tannenberg' - in particular Jews, Jesuits, Marxists, and Freemasons - were still active and trying to 'crush' the German people. ${ }^{48}$ Given his esoteric conspiracy theories, Ludendorff soon became marginalised within the radical Right, falling out with Hitler and other nationalist groups. Having once counted more than 30,000 members before its marked decline, his Tannenberg association was banned in September $1933 .^{49}$

But Ludendorff was not alone in challenging Hindenburg's status as the 'victor of Tannenberg'. Soon after the war, military experts had started to discuss the responsibility for the successful campaign, often questioning Hindenburg's individual merit and claim to fame. ${ }^{50}$ Several former high-ranking officers emphasised their own role in the decisive stages of the battle. According to Dennis Showalter, even Hindenburg's predecessor Maximilian von Prittwitz, who had failed to stop the Russian advance, 'suggested that he was the real architect of victory'. ${ }^{51}$ Max Hoffmann, who had been deputy chief of staff of the Eighth 
Army, famously told a group of officers when touring the battlefield after the war: 'See - this is where Hindenburg slept before the battle, this is where he slept after the battle, and this is where he slept during the battle. ${ }^{52}$ In his publications, Hoffmann showed himself more moderate, although he continued to criticise the various 'fairy tales' that were being reported about the battle: 'All those stories are inventions. Tannenberg is not the deed of a single man. It is the result of the extraordinary training and education of our leaders and the incomparable efforts of the German soldier. ${ }^{53}$ François similarly described the victory of Tannenberg - the 'most significant military encounter [Waffentat] of the World War' - as the consequence of the common effort, the bravery, and dedication of the German troops and their leaders. ${ }^{54}$ To many Germans, especially conservative nationalists, monarchists, and war veterans from the Stahlhelm and the Kyffhäuser League, however, Tannenberg remained intrinsically tied to Hindenburg. The former General Field Marshal was still widely regarded as a symbol of past victories and national greatness. For Paul Lindenberg, for instance, a former war correspondent on the Eastern front and editor of a lavish commemorative publication on the occasion of Hindenburg's $75^{\text {th }}$ birthday, he stood above party quarrels and embodied all the positive virtues of the German people: 'In his person, he unifies everything we consider German: loyalty, diligence, honesty, conscientiousness, and steadfastness. ${ }^{55}$

The official Reichsarchiv account of the East Prussian operations, published in 1925 as part of the series 'Der Weltkrieg 1914 bis 1918', proudly praised the victory as follows: 'Next to Leipzig, Metz, and Sedan, Tannenberg represents one of the largest encirclement battles in world history. In contrast to the others, however, it was fought against a numerically superior enemy, while both flanks were threatened by further overwhelming forces. This achievement is unique in the history of war - in Cannae, there was no threat from the rear. ${ }^{56}$ This account was followed two years later by a richly-illustrated Reichsarchiv monograph on the Battle itself, written by Theobald von Schäfer, a former Lieutenant- 
Colonel. ${ }^{57}$ Whereas the counterparts on Langemarck and Verdun had been assigned to the young right-wing writer Werner Beumelburg, whose narratives contained several literary features and dramatized elements, the Tannenberg volume was characterised by complex military-strategic discussions. ${ }^{58}$ Showalter nevertheless heavily criticised the book: 'This drum-and-trumpet narrative account, constantly contrasting German heroism with Russian incompetence, invites dismissal as Weimar revisionism at its worst. ${ }^{59}$ Indeed, Schäfer, too, presented the victory of 1914 as a triumph of German being over uncivilised Slavdom, a prime example of German greatness and singularity, and asked his fellow countrymen to find strength and comfort in the 'spirit of Tannenberg': 'No other nation has performed such a great feat of war. - This cannot be a coincidence. - May this knowledge fill every German with pride and courage in times of hardship and humiliation, but also give him the confidence that the nation which won at Tannenberg will resume and keep its standing in the world, as long as it remains true to itself and its magnificent past! ${ }^{90}$

Tannenberg as a national symbol of past and future greatness, evoked to distract from and cope with an humiliating present, as a political slogan of right-wing revisionism - these were the key features of the Tannenberg myth during the Weimar Republic. Compared to the flood of popular histories and factional military accounts of the battle, pure literary works about Tannenberg were extremely rare - a remarkable observation given the plethora of German war novels especially in the late $1920 \mathrm{~s} .{ }^{61}$ Much of this Kriegsliteratur, however, focused on the Western front, whether it glorified the combat experience and soldierly comradeship, such as Ernst Jünger's In Stahlgewittern (1920) and Josef Magnus Wehner's Sieben vor Verdun (1930), or expressed anti-war views, such as Erich Maria Remarque's Im Westen Nichts Neues (1929) and Edlef Köppen's Heeresbericht (1930). ${ }^{62}$ Indeed, there was not a single comparable work on Tannenberg. Apart from a few, fairly traditional poems and a theatre play from an obscure author, the main piece seems to have been the relevant chapter 
in Werner Beumelburg's hugely successful Sperrfeuer um Deutschland (1929), a rough account of key events of the First World War with the declared aim to "merge military actions with emotional matters' ${ }^{63}$ The combination of military history with novel-like elements is evident in the section on Tannenberg, too, despite its heavy focus on the operational considerations of key military leaders (including Prittwitz, Conrad von Hötzendorf, and Rennenkampf). Several anecdotes romanticise the battle, such as the claim that German soldiers sang the Hymn of Leuthen, which places Tannenberg into the tradition of Brandenburg-Prussian victories. The author also tells the 'sea legend', according to which the Russian troops got hopelessly lost in the woods and lakeland area: 'The leadership fails ... Grinning, panic raises its Medusa head from the swamps. ${ }^{64}$ Beumelburg’s Tannenberg chapter was later reprinted in a collection of poetic accounts of historical events. As the editor explained, he wanted to bring German history to life and to make it more accessible, allowing the readers to experience and comprehend those past episodes and figures in a different, more emotional and thus more 'authentic' way. ${ }^{65}$

Interestingly, Beumelburg's popular military history carried a short preface by Hindenburg and had in fact been approved by the President's Office only after a series of amendments, including a more conspicuous depiction of his role in the planning stages and during the battle. ${ }^{66}$ Hindenburg remained absolutely central to Tannenberg, as evidenced also by the various films on the battle. A first cinematic exploration had appeared in 1917 under the title Ostpreußen und sein Hindenburg (dir. Gustav Trautschold and Richard Schott), a chronological outline of East Prussian history since the Middle Ages that culminated in the Russian invasion, the atrocities against ordinary East Prussians, and Hindenburg's victory over the Tsarist troops. ${ }^{67}$ These two elements - the human tragedy of the civilians and the general's strategic acumen - were core themes in subsequent productions, too, such as the feature film Volk in Not. Ein Heldenlied von Tannenberg (dir. Wolfgang Neff, 1925), which 
focused largely on the home front, the Hindenburg documentaries Der Eiserne Hindenburg in Krieg und Frieden (dir. Johannes Häussler, 1929) and Einer für Alle! (dir. Curt Wesse and Heinrich Roellenbleg, 1932), and the much more famous Tannenberg, also from 1932. The latter was directed by the prolific Heinz Paul whose previous films included pieces on the Somme and Verdun. While documentary military-strategic sequences dominated Paul's Tannenberg picture (although most scenes involving the serving Reich President had to be cut at the behest of film officials), the fictional story about an East Prussian estate owner and officer whose family gets caught up in the fighting added emotional appeal, suspense, and drama - quite an exception among the numerous written and cinematic representations of the Battle of Tannenberg during the Weimar Republic. ${ }^{68}$

The National Socialist regime never really rembraced the victory of 1914 as part of its propaganda. Since the late 1920s, Adolf Hitler and his followers had been openly critical of Hindenburg, branding the Reich President a puppet in the service of deserters and 'November criminals', an Erfüllungspolitiker acting in the interest of international financiers and preventing a true national regeneration. Given the difficult economic situation and polarisation of German politics, Hindenburg in his 1931 New Year's address had called for national unity by invoking the memory of Tannenberg: 'Back then, our situation was equally difficult. ... But the bonds of mutual trust, loyal comradeship, heartfelt patriotism, and the faith in ourselves held us together firmly, so that after several days of hard struggle the end result was in our favour. Facing similarly difficult times, I once again call upon the whole of Germany to stand together loyally and united in fate.... God has rescued Germany from severe hardship before. He will not abandon us now. ${ }^{69}$ Following his appointment as Reich 
Chancellor in January 1933, Hitler pursued a placatory strategy to gain the support of military and national-conservative circles for his agenda. The reconciliation of the old and the new Germany was famously stage-managed at the Day of Potsdam in March 1933, but was also a key theme at the Tannenberg ceremony in August 1933 and Hindenburg's state funeral one year later. Both took place in the Tannenberg memorial and were attended primarily by Reichswehr formations and veterans' associations. Hoping to win over these groups following Hindenburg's death the armed forces now had to swear a personal oath of loyalty to the Führer -, Hitler and the other speakers, such as Hermann Göring, refrained from accentuating racism and anti-Semitism, emphasising instead the reconciliation of traditional Prussiandom and National Socialism. ${ }^{70}$ In this context, Hitler was often presented as the completer and enforcer of the work of Tannenberg, referring primarily to the inauguration of the memorial in 1927 and the revisionist claim to the lost eastern territories rather than to the battle of $1914 .^{71}$ Indeed, the Tannenberg of the First World War did not figure prominently in National Socialist discourse. Many obituaries for the Reich President mentioned the military victory only in passing, often presenting Hitler's appointment as German Chancellor as Hindenburg's greatest lifetime achievement and emphasising his role as "patron of the National Socialist revolution'. As Hitler's deputy Rudolf Hess declared: 'Hindenburg's living legacy for Germany is the Führer.' ${ }^{72}$ Even Hermann Oncken, an influential national-liberal historian and former supporter of the Republic, promoted such an interpretation. Trying to assess Hindenburg's European significance, Oncken argued that the victory of Tannenberg had saved not only Germany but the whole Continent, which could otherwise have come 'under the influence of Bolshevism and its Asiatic methods'. However, the historian devoted much more attention to Hindenburg's role as father of the nation and preserver of PrussoGerman ideals in the difficult period after the Treaty of Versailles. By reaching out to the National Socialists, Oncken maintained, Hindenburg had finally enabled Germany's power- 
political resurgence on the international stage, curbing French supremacy and thus restoring a stable balance of power in Europe. ${ }^{73}$ In subsequent months, the Tannenberg memorial was redesigned, adding a new emphasis on the Hindenburg crypt and turning it from a historical site commemorating the battle of 1914 into a personalized memorial for the former General Field Marshal and Reich President. Taking up an idea from the Weimar period, it was declared Germany's official war memorial (Reichsehrenmal), a 'sanctuary of the nation' and 'symbol of German loyalty, comradeship, and self-sacrifice', as Hitler explained at the unveiling ceremony on 2 October $1935 .{ }^{74}$ While these changes enhanced the status and functional purpose of the memorial, they also removed it from its original historical and local context. It remained a popular destination for school and study trips, but never again played such a prominent political role as between 1933 and $1935 .{ }^{75}$

Hindenburg's death was much lamented in conservative circles, the Reichswehr, and veterans' associations, which continued to honour his achievements during the war, including the Battle of Tannenberg. ${ }^{76}$ Despite some heated discussion about Ludendorff's role, triggered by his revisionistic Tannenberg monographs, most publications offered a fairly balanced discussion of Hindenburgian leadership in 1914 and depicted him in a complementary partnership with his chief of staff. ${ }^{77}$ They often praised the troops for their bravery and sense of duty, too, and rebutted exaggerated stories such as the 'sea legend'. Some military authors even even questioned Tannenberg's significance for the overall course of the war in view of the decisive events on the Western front. Anti-Slav rhetoric and National Socialist ideas of racial superiority hardly featured in these works, which instead celebrated Hindenburg as a devout and dutiful military leader, a brilliant strategist and 'model of true German soldierdom'. ${ }^{78}$ Only Rolf Bathe, a representative of the front generation and author of several military accounts, seems to have challenged the typical focus on senior officers and military planners in his 1939 book on Tannenberg, subtitled Der Einsatz des 
letzten Mannes. Lamenting the lack of narratives that captured the 'dramatic experience of the fighting troops' during those fateful August days, he emphasised the suffering and sacrifice of ordinary soldiers who had fought to the last breath and bullet: 'Here fought and won the Volk in Waffen!' It is worth pointing out that Bathe attributed 'this most memorable victory in German history' to the excellent spirit of the old army, the superior training of the troops, and the voluntary subordination of the individual to the collective, rather than to some racial qualities. ${ }^{79}$ Issued by the official Wehrmacht publishing house just before the outbreak of the Second World War, his book - just like most other military accounts of the battle that focused primarily on the strategic brilliance of Hindenburg - is an important reminder of the persistence of conservative attitudes within German military circles and the limits of Nazi ideological penetration.

Literary works on Tannenberg published during the Third Reich shared this traditional reading of the battle. In contrast to the 1920s, there was a veritable explosion of publications on the battle, also by relatively well-known writers, such as Joachim von Reichel, Ludwig Friedrich Barthel, Albert Benary, and Hansgeorg Buchholtz. Many of these books were popular military histories, often aimed at younger readers and including maps, photographs, as well as quotes from historical sources (e.g. military orders and army reports). ${ }^{80}$ Paul Coelestin Ettighoffer, a hugely successful author of war novels and stories, also combined factual and fictional elements in his semi-documentary 'report' on Tannenberg. First published in 1939, it went through eight editions within two years. ${ }^{81}$ Other popular works covered both historical battles (1410/1914), thus underlining East Prussia's role in Germany history as an outpost or 'bulwark of the Reich' ${ }^{82}$ Ernst Moritz Mungenast, a writer and journalist from Lorraine, put Hindenburg - the 'hero of Tannenberg' - at the centre of his bestselling Jugendbuch from 1934 which experienced seven editions by $1943 .{ }^{83}$ There were also several purely fictional works with individualised storylines, including a 
theatre play, a collection of short stories, and historical novels. ${ }^{84}$ Using fairly conventional literary techniques and motifs, they typically made a link to 1410 and focused on the martyrdom of the civilians, Russian barbarism, and Hindenburg as deus ex machina - rather than, as Bathe had demanded, the war experience of the ordinary soldier. Werner Treuenfels' book from 1934, for example, subtitled Ein vaterländischer Roman and even introduced by von François, centred primarily on the love entanglements of an accomplished tennis player an ordinary piece of light fiction that was a far cry from the captivating Frontromane of Jünger, Beumelburg, or Wehner. ${ }^{85}$ While the remarkably high circulation figures of Mungenast and Ettighoffer seem to demonstrate a continued interest of many readers in Tannenberg, neither offered a novel and distinctively völkisch interpretation of the battle. In a preface to von Reichel's historical account, published in 1934, even the East Prussian Gauleiter Erich Koch highlighted above all the decisive 'old-Prussian traditions' and virtues of 'loyalty, bravery, and dutiful conduct'. ${ }^{86}$

In 1935, a large passenger ferry was named after the battle, christened by Hindenburg's granddaughter and connecting cities on the North-German Baltic coast with East Prussia. At around the same time, the Tannenberg memorial was depicted on a stamp, part of a rare and much sought-after souvenir sheet in commemoration of the large philatelic exhibition in Königsberg (Ostropa). One year later, Heinz Paul's film from 1932 was screened in German cinemas again and several cities hosted a travelling Tannenberg exhibition, showing the busts of Hindenburg and Ludendorff, numerous books, letters, maps, and paintings, as well as a model of the East Prussian memorial. The key exhibit and focal point was a battle relief with multi-coloured lights which allowed the visitors to trace troop movements and to understand the course of the campaign. ${ }^{87}$ These examples hardly provide evidence for a 'Nazification' of the memory of the victory. Indeed, Tannenberg never played a particularly prominent role in Nazi ideology and propaganda, even after the outbreak of the 
Second World War. The ceremony in celebration of the twenty-fifth anniversary of the battle in late August 1939, which was to involve 10,000 Tannenberg veterans, was cancelled at the last minute (and the tented quarter quickly transformed into a camp for Polish POWs). ${ }^{88}$ Given its Eastern and anti-Slav connotations, Tannenberg was used as a code name on several occasions, such as the false flag attack on the German radio station in Gleiwitz on 1 September 1939 or the mass arrest and executions of Polish nationals by SS Einsatzgruppen.

In summer 1944, it was the namesake for a military operation (or rather defensive line) of Wehrmacht and multinational Waffen-SS troops who defended the Narva Isthmus against the Soviet advance into Estonia, Finland, and East Prussia. Not least because of the substantial involvement of local units on the German side, the Battle of the Tannenberg Line (or the Battle of the Blue Hills, as it is also known) has since occupied an important place in Estonian collective memory. ${ }^{89}$ In Germany itself, on the other hand, it seems that the $30^{\text {th }}$ anniversary of the battle of 1914 was not celebrated or commemorated. Tannenberg was briefly brought up by Hermann Göring in his obituary speech for General Günther Korten, who had been one of the victims of Claus von Stauffenberg's assassination attempt on Hitler in July 1944 and was buried in the Reichsehrenmal: 'Tannenberg, a bright name in the annals of German history; a symbol to which you had often payed homage, my dear friend; a symbol how one can defeat superior forces with only few troops, as long as there is a strong will and a strong faith. If we carry this faith as much in our hearts as you did, the final victory will and must come. ${ }^{90}$ However, it appears that the triumph over the tsarist troops in summer 1914 was not brought up and utilised as a morale-boosting slogan when Russian forces once again invaded East Prussian territory in January $1945 .{ }^{91}$ 
Tannenberg featured the typical elements of historical myths: a relatively simple but extraordinary story of resilience and ultimate victory over a stereotypical enemy; popularised in films, literary works, and memorials; ritualised and regularly commemorated in speeches and ceremonies on certain anniversaries; and serving an integrative and mobilising function, encouraging future generations to defend and carry on this Germanic mission against the Slavs. $^{92}$ The battle occupied a particularly important place in East Prussian collective memory, as evidenced by the extensive literature dedicated to the experience of the local population and the unbroken popularity of Paul von Hindenburg. Given the region's post-war position as an isolated exclave, Tannenberg here underlined and affirmed East Prussia's historic role as German watch in the East. ${ }^{93}$ While the victory carried much symbolic and national significance in the rest of Germany, too, it ultimately remained tied to Prussianconservative circles and admirers of Hindenburg's ingenious leadership. Tannenberg conveyed a conventional, antiquated image of the war and had little in common with the experience of many German soldiers, with the horrors of trench warfare and attrition on the Western front that dominated the German image of the war after 1918. Arguably, it never gained the same status in German collective memory as the 'heroic' but futile assault of inexperienced war volunteers near Langemarck in Flanders - also expressing a more 'romantic' idea of the war - or the drawn-out, merciless Battle of Verdun. ${ }^{94}$ The latter myths revolved around a different generation and set of protagonists: the enthusiastic students in Belgium and the ascetic-nihilistic (but no less loyal) Frontkämpfer in the trenches of eastern France. This related to different notions of heroism and sacrifice: while Langemarck stood for the patriotism of the German youth and its willingness to make sacrifices, Verdun epitomised a more silent, robust kind of valour and devotion. These heroic narratives allowed the (male) reader to identify with the central characters, which was difficult in the case of the more complex Tannenberg myth with its references to the medieval past and the world-historical 
struggle between Germandom and Slavdom, its focus on civilian suffering and sacrifices, and the glorification of a retired Prusso-German aristocrat who could hardly serve as the exemplary hero of soldierly masculinity and bravery in the age of modern and technologized mass warfare. ${ }^{95}$ This may explain the relatively small number of literary and fictional texts on Tannenberg - as opposed to the many popular military histories and memoirs of high-ranking officers -, despite the efforts of a few authors to dissociate the myth from Hindenburg and to 'modernise' the narrative by focusing more on the role of ordinary soldiers and the Volk in Waffen..${ }^{96}$ Ultimately, however, the attempt to liberate the battle from 'history' and to subject the 'objective truth' of the event to poetic and dramatic exploration, was a rare exception. Tannenberg remained a predominantly political myth, promoted and supported by nationalist and conservative groups to challenge the territorial changes and - as a defensive battle on German soil - the 'war guilt lie' of the Treaty of Versailles. It would be worth investigating to what extent the notion of the Russian army as a numerically superior but disorganised and faint-hearted enemy contributed to Hitler's fateful underestimation of the Soviet Union's military potential, and whether many East Prussians really expected another miracle victory and thus failed to escape in time when the Red Army invaded the region in 1945, as has been suggested by some historians. ${ }^{97}$ In any case, following the destruction of the Reichsehrenmal by German pioneers in January 1945, the downfall of the Third Reich and total defeat, and the loss of East Prussia, the Tannenberg of 1914 has outlived its usefulness as a myth in Germany. ${ }^{98}$ The medieval victory over the Teutonic Knights at the Battle of Grunwald, on the other hand, is still widely celebrated as one of the most glorious and significant events in Polish history - another example for the persistant symbolic and political power of 'battle myths' in national identity and collective memory.

\footnotetext{
${ }^{1}$ I should like to thank Bernd Hüppauf, Michael Wintle, Cathie Carmichael, T.G. Otte, as well as the anonymous peer reviewers for their insightful comments on earlier versions of this essay.
} 
${ }^{2}$ There are remarkably few comparative studies on battle myths. See, however, Krumeich and Brandt, eds., Schlachtenmythen.

${ }^{3}$ Schivelbusch, Kultur der Niederlage and Macleod, ed., Defeat and Memory.

${ }^{4}$ On the memory of the First World War see in particular Eksteins, Rites of Spring; Winter, Sites of Memory; as well as the relevant chapters in Winter, ed., The Cambridge History, III: Civil Society. With a focus on Britain: Fussell, The Great War; Todman, The Great War; Reynolds, The Long Shadow. For Germany, see Hüppauf, ed., War, Violence, and the Modern Condition; Ziemann, "Die Erinnerung an den Ersten Weltkrieg"; Rohkrämer, "Ideenkrieg".

${ }^{5}$ Goebel, The Great War, 127.

${ }^{6}$ For brief overviews, see Janßen, "Tannenberg"; Afflerbach, "Erst Dampfwalze"; Kossert, "Tannenberg 1914"; Nagornaya, "Tannenberg Myth".

7 See Schenk, "Tannenberg/Grunwald"; Olivier, "Schlacht bei Tannenberg"; Goebel, "The German Crusade".

${ }^{8}$ Hoegen, Der Held von Tannenberg; Goltz, Hindenburg. Also see Maser, Hindenburg; Lehnert, "Die geschichtlichen Schattenbilder"; Rauscher, Hindenburg; and Pyta, Hindenburg.

${ }^{9}$ For the sake of readability and historical accuracy, I am using contemporary German names of East Prussian localities.

${ }^{10}$ For a short overview of the military campaign, see Pöhlmann, "Tod in Masuren"; Heitmann, "Von der 'Schlacht in Ostpreußen",; Zimmermann, "Die Schlacht von Tannenberg 1914". For more

detailed studies, see Showalter, Tannenberg; Sweetman, Tannenberg 1914; and Buttar, Collision of Empires.

${ }^{11}$ One of the first journalists to speak of the 'Battle of Tannenberg' was Theodor Wolff in his Monday column for the Berliner Tageblatt on 31 August 1914, reprinted in Wolff, Vollendete Tatsachen, 11 13.

${ }^{12}$ Ekdahl, Die Schlacht bei Tannenberg; idem, “Tannenberg/Grunwald”; idem, "Die Grundwald-

Denkmäler"; Mick, "Den Vorvätern zum Ruhm,"

${ }^{13}$ Wippermann, Der Ordensstaat als Ideologie; Althoff, "Die Beurteilung der mittelalterlichen Pstpolitik".

${ }_{15}^{4}$ Hindenburg, Aus meinem Leben, 85.

15 "Die Unglücksschlacht bei Tannenberg. Eine Erinnerung an 1410." Königsberger Woche, 18 September 1914. Also see already "Von der Schlacht an den masurischen Seen." Ibid., 11 September 1914.

${ }^{16}$ Ernst Zittau, “Bei Tannenberg.” Königsberger Woche, 11 September 1914:

\section{Bei Tannenberg}

Bei Tannenberg in Wald und Ried

Verklang ein stolzes Heldenlied:

Jagiello der Masure

Besiegte dort die deutschen Herrn,

Hinsank des Ordens Glück und Stern,

Hinsanken die Komture.

Und Baltenland und Lettenland

Die fielen in der Slawen Hand,

Das deutsche Schwert im Osten

Schien zu verrosten.
Bei Tannenberg in Wald und Ried

Aufklingt ein stolzes Heldenlied:

Die Landwehr aus Ostpreußen

Hat dreimal Tag und Nacht gekämpft

Und hat in Strömen Bluts gedämpft

Den Uebermut der Reußen.

Die deutsche Klinge ward nichtstumpf

Sie trieb den Feind in See und Sumpf

Sie schlug ihn schwer danieder.

Wir lösen ein das Ehrenpfand

Hei Baltenland, hei Lettenland,

Die Deutschen kommen wieder!

For similar examples, see Albert Matthäi, "Das Marienburger Lied." Ibid., 28 August 1914; Franz Hirsch, "Zum ostpreußischen Sieg." Ibid., 4 September 1914; E. Mayer, "Tannenberg." In VolksPoesie aus großer Zeit, edited by Hall and Ackermann, 191. The East Prussian medievalist and Professor of History at the University of Halle Albert Werminghoff published a popular history of both battles: Die Schlacht bei Tannenberg.

${ }^{17}$ See Anz and Vogl, eds., Die Dichter und der Krieg; Detering et al., eds., Populäre Kriegslyrik. 
${ }^{18}$ Eugen Zabel, "Den Russen.” Königsberger Woche, 4 September 1914; Gustav Schüler, "Ostpreußen." Ibid.; Caliban, "Hunneneinfall." Ibid.

${ }^{19}$ Fritz Kudnig, “Ostpreußisches Flüchtlingselend. Dem Leben nacherzählt.” Königsberger Woche, 18 March 1915.

${ }^{20}$ Watson, "'Unheard-of Brutality"”.

${ }^{21}$ See e.g. "Ostpreußische Flüchtlinge." Illustrierte Geschichte des Weltkrieges 1914/15, 1 (1915): 7982. On the German reactions see Jahn, "“Zarendreck, Barbarendreck"”.

${ }^{22}$ Alfred Kerr, “Ostpreußen.” In Liebe und Trompetenblasen, ed. by Schloemp, 17-18:

\author{
Ostpreußen \\ Ist dein Land, Immanuel Kant, \\ Von den Skythen überrannt? \\ Mit Gestank und mit Gelärme \\ Stapfen stumpfe Steppenschwärme. \\ Hunde drangen in das Haus - \\ Peitscht sie raus! [...] \\ Dürfen uns nicht unterkriegen - \\ Peitscht sie, daß die Lappen fliegen. \\ Zarendreck, Barbarendreck -
}

${ }^{23}$ See e.g. "Die Schlacht bei Ortelsburg und Gilgenburg." Illustrierte Geschichte des Weltkrieges 1914/15, 1 (1915): 52-54; Katarina Botsky, "Der masurische Fischzug.” Königsberger Woche, 11 March 1915.

${ }^{24}$ For some typical examples, see Walter Flex, “Ostdeutsches Kinderlied.” Ibid., 25 September 1914; Hans Philipp, "Die Seen Masurens.” Ibid., 2 October 1914; Karl Scheidemantel, "Die Schlacht an den masurischen Seen. Nach der bekannten Melodie zu singen: 'Als die Römer frech geworden'." Ibid., 13 April 1916; Franz Karl Ginzkey, "Ballade von den Masurischen Seen (Hindenburg-Ballade)." Neue deutsche Bilderbogen für Jung und Alt, 17 (1915); Josef Schmidt, "Hindenburg." In VolksPoesie aus großer Zeit, edited by Hall and Ackermann, 170; Gertrud Schweizer, "Hindenburg." Ibid., 206; Johann B. Haindl, "Hindenburg." In Schwert und Harfe, ed. by Haindl, 124. For a more general discussion of German images of the Slav enemy, see Hoeres, "Die Slawen".

${ }^{25}$ On the Hindenburg myth in World War One, see also Hoegen, Der Held von Tannenberg, 35-215 and Goltz, Hindenburg, 14-57.

26 “An Feldmarschall von Hindenburg.” Süddeutsche Monatshefte, July 1915: 561-62 (561). For a similar argument, see Julius Bab, "Der Hindenburg-Mythos." Gegenwart, 15 September 1915: 596600.

${ }^{27}$ Max Grunwald, "Hindenburg. Nachträgliches zu seinem 68. Geburtstage (2. Oktober 1915)." Glocke, 15 October 1915: 217-20 (217-18).

${ }^{28}$ Niemann, Hindenburgs Siege, 21.

${ }^{29}$ See e.g. the appendix "Auf der Wacht im deutschen Osten (Unterrichtliche Stoffe und Entwürfe zum Weltkriege.)." In Die Schule und der Krieg, edited by Hantke, 34-61 (quotes on page 53).

${ }^{30}$ See e.g. K.F. Langenbach, "Marschall Vorwärts im Osten.” Königsberger Woche, 18 September 1914; Robert Misch, "Die drei großen Kameraden." Ibid., 7 April 1916; Felix Neumann, "Feldmarschall von Hindenburg." Die Woche, 29 September 1917.

${ }^{31}$ Ganghofer, Bei den Heeresgruppen, 12.

${ }^{32}$ A. de Nora, 'Das Lied vom Hindenburg. Ein Soldatenlied.”, Thüringer Lehrerzeitung, 6 May 1915. Also see e.g. Theodor Krausbauer, "Wer hält die Wacht im Osten." Königsberger Woche, 25 September 1914; Richard Schaukal, "Generaloberst Hindenburg." Ibid., 2 October 1914; Julius Schultz, "Hindenburg." Ibid., 26 November 1914; Ernst Hardt, "Hindenburg." Ibid., 7 April 1916. For many more examples of Hindenburg and Tannenberg songs of the First World War, see Helms, "'Das war der Herr von Hindenburg"” and idem et al., "'Und dich grüßt so manches Lied"”.

${ }^{33}$ Stefan George, 'Der Krieg' (1917), in idem, Gedichte, 140-44 (142).

${ }^{34}$ Neumann, Tannenberg, 8. 
${ }^{35}$ Brechenmacher, Die Riesenschlacht bei Tannenberg; Arminius, Der Russenschreck; idem, Der Spion von Tannenberg; Denk, Der Rattenfänger von Tannenberg. For theatre plays see e.g. Buschmann, Wiedergefunden and Vogeler, Tannenberg.

${ }^{36}$ Compare Hindenburg-Bibliographie, edited by Deutsche Bücherei; Der Kreis Neidenburg/Ostpr., edited by Knieß.

${ }^{37}$ For some early Hindenburg pieces by military experts, witness reports, and biographical studies, which emphasised the centrality of Tannenberg, see e.g. Pochhammer, Paul von Hindenburg; Strecker, Von Hannibal zu Hindenburg; Ekkehard, Von Berlin bis Tannenberg; Fischer, Tannenberg 1914; Skowronnek, Hindenburg; Bracht, Unter Hindenburg.

${ }^{38}$ Goltz, Hindenburg, p. 25.

${ }^{39}$ See Kitchen, The Silent Dictatorship, and in addition to the Hindenburg studies mentioned above, Nebelin, Ludendorff.

${ }^{40}$ Both Tannenberg and Hindenburg remained hugely popular in East Prussia until the end of the war. For typical examples, see the special issue of the Königsberger Woche: "Hindenburgnummer. Dem Befreier Ostpreußens zum Goldenen Militär-Jubiläum!", 7 April 1916; Leipacher, Die Russenflut.

${ }_{41}^{4}$ Ludendorff, Meine Kriegserinnerungen, 44-45, 53.

${ }_{42}^{42}$ François, "Tannenberg", 114.

${ }_{44}^{43}$ Goebel, The Great War, 128-29.

${ }^{44}$ Vogelsang, "Aus der Geschichte des Reichsehrenmals Tannenberg"; Fischer, "TannenbergDenkmal"; Tietz, Das Tannenberg-Nationaldenkmal.

45 Quoted from Vogelsang, "Aus der Geschichte", 80-81.

${ }^{46}$ See the photo in Kahns, Das Reichsehrenmal Tannenberg, 22.

${ }^{47}$ Ebeling, Tannenberg 1410/1914, 94-95.

${ }_{49}^{48}$ Ludendorff, Tannenberg. Zum 20. Jahrestag, 45.

${ }^{49}$ On the Tannenberg-Bund and Ludendorff's relationship to Hitler, see Finker, "Tannenberg-Bund" and Amm, "Die Ludendorff-Bewegung".

${ }_{51}$ Zimmermann, "Von den operativen und erinnerungsgeschichtlichen Dimensionen eines Raumes".

${ }_{52}^{51}$ Showalter, Clash, 329.

52 Quoted from Rauscher, Hindenburg, 39.

${ }_{54}^{53}$ Hoffmann, Tannenberg, 90.

${ }^{54}$ François, Tannenberg, 71, 30-32. For another critical account of Hindenburg's role, but also of the Russjan atrocities and the 'sea legend', see Goldsmith and Voigt, Hindenburg. The book was translated into German in 1930 .

${ }_{5}^{5}$ Lindenberg, Das Buch vom Feldmarschall Hindenburg, V. Also see his Hindenburg-Denkmal.The Hindenburg cult of the 1920 s produced innumerable publications, biographical studies, pamphlets, and other hagiographic material. See Hindenburg-Bibliographie, edited by Beutsche Bücherei.

${ }^{56}$ Reichsarchiv, ed, Der Weltkrieg 1914 bis 1918. Die militärischen Operationen zu Lande, 14 vols. Berlin: Mittler,' 1925-44, II: Die Befreiung Ostpreußens (1925): 242-43.

${ }_{58}$ Schäfer, Tannenberg.

${ }^{58}$ See Beumelburg, Douaumont and idem, Ypern 1914. The writer published two further volumes within the Reichsarchiv series.

${ }^{59}$ Showalter, Clash, 409.

${ }^{60}$ Schäfer, Tannenberg, 253-54.

${ }^{61}$ See, in addition to François, Hoffmann, and Schäfer: Stephani, Mit Hindenburg bei Tannenberg; Giehrl, Tannenberg; Elze, Tannenberg; Szczepanski, Tannenberg 1914.

${ }^{62}$ For two notable exceptions see Hans Carossa's Rumänisches Tagebuch (1924) and Arnold Zweig's Streit um den Sergeanten Grischa (1927). On German Kriegsliteratur, see Müller, Der Krieg und die Schriftsteller; Schneider and Wagener, eds., Von Richthofen bis Remarque.

${ }^{63}$ Beumelburg, Sperrfeuer um Deutschland, 7. For the play, see Müller-Raabe, Tannenberg-

Weihespiel. For other literary works, see Hindenburg-Bibliographie, edited by Deutsche Bücherei.

${ }^{64}$ Beumelburg, Sperrfeuer um Deutschland, p. 51.

${ }^{65}$ Heider (ed.), Deutsche Geschichte, 7-8. A shortened version of Beumelburg's Tannenberg chapter was reprinted as "Tannenberg - 1914", 461-66.

${ }^{66}$ See Goltz, Hindenburg, 112-13, although she wrongly describes the book as a 'novel'. 
${ }^{67}$ Also see the film booklet by Schott, Ostpreussen und sein Hindenburg.

${ }^{68}$ Kester, Film Front Weimar, 112-22 and Goltz, Hindenburg, 104-9. Apparently, there was also a 'military instruction film', entitled Tannenberg (1927), about which very little is known.

${ }^{69}$ An audio file of the speech can be found at: http://www.dhm.de/lemo/jahreschronik/chronik1931.html.

${ }^{70}$ For the two Tannenberg ceremonies and the speeches there, see Tannenberg 1914-1933 and Hindenburg. Feldherr und Soldat.

${ }^{71}$ For a typical example, see Walter-Schomburg (ed.), Die Treue ist das Mark der Ehre.

72 "Die Ansprache des Führers" (7 August 1934). In Hindenburg. Feldherr und Soldat, 74-77 (76); "Der Stellvertreter des Führers an die nationalsozialistische Bewegung" (4 August 1934). Ibid., 57.

${ }^{73}$ Oncken, "Hindenburg", 126. In 1935, he nevertheless lost his chair at the University of Berlin for political reasons. For another liberal, but much more restrained obituary, see Theodor Heuss, "Hindenburg." Die Hilfe, 18 August 1934: 361-64.

74 "Kundgebung." In Tannenberg. Deutsches Schicksal, edited by Kuratorium, 5. For other contemporary publications on the memorial see Tannenberg 1914-1933; Buchheit, Das Reichsehrenmal Tannenberg; Kahns, Das Reichsehrenmal Tannenberg; Buchholtz, Reichsehrenmal Tannenberg. For a detailed discussion of the architectural changes, see Tietz, TannenbergNationaldenkmal, 85-154.

${ }^{75}$ According to Vogelsang, the memorial was visited by c. 50,000 people each year between 1928 and 1932, not including mass demonstrations. The nearby youth hostel was the second most-visited in East Prussia after Königsberg. See Vogelsang, "Aus der Geschichte”, 89-91.

${ }^{6}$ See. e.g. Schulenburg, Welt um Hindenburg; Haeften, Hindenburg und Ludendorff; Frentz, Hindenburg und Ludendorff; Rohrscheidt, Ubber Ștallupönen und Gumbinnen; Lezius, Tannenberg; Grosse, Tannenberg 1914; Kabisch, "Tannenberg".

For the Ludendorff debate, see Ludendorff, Tannenberg. Zum 20. Jahrestag; idem, Tannenberg. Geschichtliche Wahrheit; Lezius, Ludendorff; Müller-Eberhart, Kopf und Herz des Weltkrieges; Sichäter, Ludendorff.

78 Joachim von Stuilpnagel "Hindenburg zu seinem 90. Geburtstage. Das Vorbild ewigen deutschen Soldatentums." Die Wehrmacht, 2 September 1937:3.

Bathe, Tannenberg, 7-8. Also see already his "Tannenberg - der größte Tag der alten Armee." Koyffhäuser, 30 August 1936: 929-31.

81 Benary, Die Schlacht bei Tannenberg; Kürenberg, Russlands Weg; van Wehrt, Tannenberg.

${ }_{82}^{81}$ Ettighoffer, Tannenberg. ${ }^{82}$ Bürger, Bei Tannenberg zwei Schlachten, 96 . Also see Wichert, Tannenberg and the historical
gyverview by Maschke "Deutsche Wacht im Osten".

${ }_{84}$ Mungenast, Der Held von Tannenberg.

${ }^{84}$ Elsner, Die Schlacht bei Tannenberg; Barthel, Tannenberg; Hofmann, Der Held von Tannenberg; Buchholtz, Der Schnitter griff zur Sense; Schnackenburg, Der Schuss im Walde von Chorzele.

${ }_{5}$ Treuenfels, Der Geist von Tannenberg. On the Weltkriegsromane of the Third Reich which were often quite traditional, continuing tendencies from the pre-1933 period and highlighting notions such as comradeship, leadership, courage, and sacrifice, rather than distinctively National Socialist creeds, such as anti-Semitism, anti-Bolshevism, racism, or Blut und Boden, see Prumm, "Das Erbe der Front" and Baird, Hitler's War Poets.

86 "Geleitwort des Gauleiters von Ostpreußen Erich Koch." In Kürenberg, Russlands Weg, 5-7 (6).

${ }^{87}$ Major Schnarke, "Ein Tannenberg-Relief." Kyffhäuser, 30 August 1936: 931.

${ }^{88}$ On the role of Tannenberg between 1935 and 1939 see also Vogelsang, "Aus der Geschichte", 8893.

${ }^{89}$ See, for instance, two recent Estonian films: the 2005 documentary Sinimäed (The Blue Hills) by Raimo Jõerand and the war drama 1944, directed by Elmo Nüganen(2015).

${ }^{90}$ Völkischer Beobachter, 1 August 1944.

${ }^{91}$ This is based on a close reading of the relevant issues of the Völkischer Beobachter.

${ }^{92}$ See Münkler, "Politische Mythen"; Saldern, "Mythen, Legenden und Stereotypen”; Schöpflin, "The Functions of Myth". 
${ }^{93}$ On East Prussian collective memory, see Traba, "Kriegssyndrom in Ostpreußen" and Kossert, Ostpreußen.

${ }^{94}$ On Langemarck and Verdun, see Ketelsen, “'Die Jugend von Langemarck”"; Dithmar, ed., Der Langemarck-Mythos; Werth, Verdun; Hüppauf, "Langemarck, Verdun and the Myth of a "New Man"; idem, "Schlachtenmythen"; Krumeich, "Langemarck"; Krumeich and Prost, Verdun 1916; Weinrich, "Kult der Jugend".

${ }^{95}$ In a remarkable but far from representative essay, the right-wing author Albrecht Erich Günther lamented the fact that Verdun - as a 'symbol of futility' and with its ostensible emphasis on dull and 'feminine' suffering - had overshadowed Tannenberg which in his view stood for the uncompromising and 'masculine will to win and to destroy'. See Günther, "Tannenberg und Verdun", 831 and 833.

${ }_{96}$ In fact, the most important and sophisticated literary text on the battle stems from a Russian author, offering a historically accurate depiction of the tragedy of military failure from the highest ranks down to the fate of individual soldiers. See Solzhenitsyn, August 1914.

${ }_{97}^{97}$ See Showalter, Clash; Afflerbach, "Erst Dampfwalze"; and Kossert, "Tannenberg 1914".

98 On the legacy and image of Hindenburg and Tannenberg after 1945, see Tietz, TannenbergNationaldenkmal, 201-7 and Goltz, Hindenburg, 193-210.

\section{Bibliography}

Afflerbach, Holger, "Erst Dampfwalze ... dann Sandkastenspiel.” Zeit, 26 August 1994: 58.

Althoff, Gerd, "Die Beurteilung der mittelalterlichen Ostpolitik als Paradigma für zeitgebundene Geschichtsbewertung." In Die Deutschen und ihr Mittelalter. Themen und Funktionen moderner Geschichtsbilder vom Mittelalter, edited by Gerd Althoff, 147-64. Darmstadt: Wissenschaftliche Buchgesellschaft, 1992.

Amm, Bettina, "Die Ludendorff-Bewegung im Nationalsozialismus - Annäherung und by Abgrenzungsversuche." In Die völkisch-religiöse Bewegung im Nationalsozialismus, edited

Uwe Puschner and Clemens Vollnhals. 127-41. Göttingen: Vandenhoeck \& Ruprecht, 2012.

Anz, Thomas and Joseph Vogl, eds., Die Dichter und der Krieg. Deutsche Lyrik 1914-1918. Munich: Hanser, 1982 .

Arminius, Wilhelm [i.e. Wilhelm Herrmann Schultze], Der Russenschreck. Eine Erzählung für die

Jugend aus den Tagen der Schlacht bei Tannenberg. 2nd ed. Stuttgart: Levy \& Muiller, 1915.
Arminius, Wilhelm [i.e. Wilhelm Herrmann Schultze], Der Spion von Tannenberg. Eine Erzählung für

Baird, Jay W., Hitler's War Poets: Literature and Politics in the Third Reich. Cambridge: Cambridge

Barthel, University Press, 2008. Friedrich, Tannenberg. Ruf und Requiem. Jena: Diederichs, 1934.

Bathe, Rolf, Tannenberg. Der Einsatz des letzten Mannes. Berlin: Die Wehrmacht, 1939.

Benary, Albert, Die Schlacht bei Tannenberg. Berlin: Franz Schneider, 1933.

Beumelburg, Werner, Douaumont. Oldenburg: Stalling, 1923.

Beumelburg, Werner, Ypern 1914. Oldenburg: Stalling, 1924.

Beumelburg, Werner, Sperrfeuer um Deutschland. Oldenburg: Stalling, 1940

Bracht, Reinhard, Unter Hindenburg von Tannenberg bis Warschau. Berlin: Mittler, 1917.

Brechenmacher, Josef Karlmann, Die Riesenschlacht bei Tannenberg. Schilderungen aus dem Weltkrieg. Dem deutschen Volk und der deutschen Jugend dargeboten (Donauwörth: Auer, 1915).

Buchheit, Gert, Das Reichsehrenmal Tannenberg. Seine Entstehung, seine endgültige Gestaltung und seine Einzelkunstwerke. Munich: Knorr \& Hirth, 1936.

Buchholtz, Hansgeorg, Der Schnitter griff zur Sense. Tannenberg-Novellen. Königsberg: Graefe \& Unzer, 1939.

Buchholtz, Hansgeorg, Reichsehrenmal Tannenberg. Hohenstein: Verkehrsverein Tannenberg, 1940. 
Bürger, Heinz, Bei Tannenberg zwei Schlachten. Ritter und Feldherren auf Wacht im Osten. Stuttgart: Union Deutsche Verlagsgesellschaft, 1935.

Buschmann, Alois, Wiedergefunden oder Der Sieg bei Tannenberg. Dreiakter. Paderborn: Esser, 1915.

Buttar, Prit, Collision of Empires: The War on the Eastern Front 1914. Oxford: Osprey, 2014.

Denk, Viktor Martin Otto, Der Rattenfänger von Tannenberg. Erzählung aus dem Masurenland. Munich: Manz, 1916.

Detering, Nicolas, et al., eds., Populäre Kriegslyrik im Ersten Weltkrieg. Münster: Waxmann, 2013.

Deutsche Bücherei, ed., Hindenburg-Bibliographie. Verzeichnis der Bücher und Zeitschriftenaufsätze von und über den Reichspräsidenten Generalfeldmarschall von Hindenburg. Leipzig: Bibliographisches Institut, 1938.

Dithmar, Reinhard (ed.), Der Langemarck-Mythos in Dichtung und Unterricht. Neuwied: Luchterhand, 1992.

Ebeling, Max, Tannenberg 1410/1914. Das Tannenberg-Denkmal-ein nationaler Wallfahrtsort im deutschen Osten. Frankfurt/O.: Heilige Ostmark, 1929.

Ekdahl, Sven, Die Schlacht bei Tannenberg 1410. Quellenkritische Untersuchungen. Berlin: Duncker \& Humblot, 1982.

Ekdahl, Sven, "Tannenberg/Grunwald - ein politisches Symbol in Deutschland und Polen." In Deutscher Orden 1190-1990, edited by Udo Arnold, 241-302. Lüneburg: Institut Nordostdeutsches Kulturwerk, 1997

Ekdahl, Sven, "Die Grundwald-Denkmäler in Polen. Politischer Kontext und nationale Funktion." Nordost-Archiv, NF VII (1998): 75-108.

Ekkehard, Heinrich, Von Berlin bis Tannenberg. Erlebnisse eines Kriegsteilnehmers unter Generalfeldmarschall von Hindenburg. 5th ed. Berlin: Bermühler, 1915.

Eksteins, Modris, Rites of Spring: The Great War and the Birth of the Modern Age. Boston: Houghton Mifflin, 1989.

Elsner, Richard, Die Ś chlacht bei Tannenberg. Eine Tragödie. Berlin: Heyer, 1933.

Elze, Walter, Tannenberg. Das deutsche Heer von 1914, seine Grundzüge und deren Auswirkung im Sieg an der Ostfront. Breslau: Hirt, 1928.

Ettighoffer, Paul C., Tannenberg. Eine Armee wird zu Tode marschiert. Ein Bericht. Gütersloh: Bertelsmann, 1939.

Finker, Kurt, "Tannenberg-Bund. Arbeitsgemeinschaft völkischer Frontkrieger und Jugendverbände der (TB) 1925-1933." In Die bürgerlichen Parteien in Deutschland. Handbuch der Geschichte bürgerlichen Parteien und anderer bürgerlicher Interessenorganisationen vom Vormärz bis zum Jahre 1945, edited by Dieter Fricke, II: 668-71. Leipzig: Verlag Enzyklopädie, 1970.

Fischer, Heike, "Tannenberg-Denkmal und Hindenburgkult. Hintergründe eines Mythos", In des Unglücklich das Land, das Helden nötig hat. Leiden und Sterben in den Kriegśdenkmälern Ersten und Zweiten Weltkrieges, edited by Michael Hütt et al., 28-49. Marburg: Jonas-Verlag, 1990.

Fischer, Paul, Tannenberg 1914 und 1410. Lissa i.P.: Eulitz, 1915.

François, Hermann von, Tannenberg. Das Cannae des Weltkrieges in Wort und Bild. Berlin:

Deutscher Jägerbund, 1926.

François, Hermann von, “Tannenberg.” In Hindenburg-Denkmal, edited by Lindenberg, 91-116.

Frentz, Hans, Hindenburg und Ludendorff und ihr Weg durch das deutsche Schicksal. Ein Beitrag zur Deutung ihrer geschichtlichen Persönlichkeit. Berlin: Morawe \& Scheffelt, 1937.

Fussell, Paul, The Great War and Modern Memory. London: Oxford University Press, 1975.

Ganghofer, Ludwig, Bei den Heeresgruppen Hindenburg und Mackensen. Stuttgart: Bonz, 1916.

George, Stefan, Gedichte, edited by Günter Baumann. Stuttgart: Reclam, 2004.

Giehrl, Hermann, Tannenberg. Berlin: Mittler, 1923. 
Goebel, Stefan, The Great War and Medieval Memory: War, Remembrance and Medievalism in Britain and Germany, 1914-1940. Cambridge: Cambridge University Press, 2007.

Goebel, Stefan, "The German Crusade: The Battles of Tannenberg, 1410 and 1914.” In Chivalry and the Medieval Past, edited by Katie Stevenson and Barbara Gribling, 169-86. Woodbridge: The Boydell Press, 2016.

Goldsmith, Margaret, and Frederick Voigt, Hindenburg: The Man and the Legend. London: Faber \& Faber, 1930.

Goltz, Anna von der, Hindenburg: Power, Myth, and the Rise of the Nazis. Oxford: Oxford University Press, 2009.

Grosse, Walther, Tannenberg 1914. Eine kurze Darstellung der großen Vernichtungsschlacht. Königsberg: Ost-Europa-Verlag, 1939.

Günther, Albrecht Erich, “Tannenberg und Verdun.” Deutsches Volkstum, November 1936: 826-33.

Haeften, Hans von, Hindenburg und Ludendorff als Feldherren. Berlin: Mittler, 1937.

Haindl, Josef B., In Schwert und Harfe. Kriegslieder. 2nd ed. Munich: Leohaus, 1915.

Hall, Wilhelm, and Robert Ackermann, eds., Volks-Poesie aus großer Zeit. Cologne: Hall \& Ackermann, 1916.

Hanheide, Stefan, et al., eds., Musik bezieht Stellung. Funktionalisierungen der Musik im Ersten Weltkrieg. Göttingen: V \& R unipress, 2013

Hantke, Max, ed., Die Schule und der Krieg. 2nd ed. Langensalza: Beyer, 1915.

Heider, Werner, ed., Deutsche Geschichte von Dichtern gesehen. Berlin: Hobbing, 1935.

Heitmann, Clemens, "Von der 'Schlacht in Ostpreußen' zum Tannenberg-Mythos. Eine dfeutsche Legende." Militärgeschichte, 1 (2004): 10-13.

Helms, Dietrich, "'Das war der Herr von Hindenburg'. Mythenbildung und informelle Propaganda in der deutschen Musikproduktion des Ersten Weltkriegs." In Musik bezieht Stellung, edited by Hanheide et al., 63-100.

Helms, Dietrich, et al.," "Und dich grüßt so manches Lied'. Verzeichnis von Liedern über Paul von Hindenburg."'In Musik bezieht Stellung, edited by Hanheide et al., 101-20.

Hindenburg, Paul von, Aus meinem Leben. Leipzig: Hirzel, 1920.

Hindenburg. Feldherr und Soldat. Berlin: Siegismund, 1935.

Hoegen, Jesko von, Der Held von Tannenberg. Genese und Funktion des Hindenburg-Mythos. Cologne: Böhlau, 2007.

Hoeres, Peter, "Die Slawen: Perzeptionen des Kriegsgegners bei den Mittelmächten." In Die vergessene Front-der Osten 1914/15, Ereignis, Wirkung, Nachwirkung, edited by Gerhard P. Groß, 179-
200. Paderborn: Schöningh, 2006 .

Hofmann, Eugen, Der Held von Tannenberg. Dramatische Dichtung in drei Akten. Bamberg: Maar, 1936.

Hoffmann. Max, Tannenberg wie es wirklich war. Berlin: Verlag für Kulturpolitik, 1926.

Hüppauf, Bernd, ed., War, Violence, and the Modern Condition. Berlin: De Gruyter, 1997.

Hüppauf, Bernd, "Langemarck, Verdun and the Myth of a 'New Man' in Germany after the First World War." War and Society 6/2 (1988): 70-103.

Hüppauf, Bernd, "Schlachtenmythen und die Konstruktion des 'Neuen Menschen'.” In "Keiner fühlt Gerhard sich hier mehr als Mensch..." Erlebnis und Wirkung des Ersten Weltkrieges, edited by

Hirschfeld et al., 43-84. Essen: Klartext, 1993.

Jahn, Peter, “'Zarendreck, Barbarendreck - Peitscht sie weg!' Die russische Besetzung Ostpreußens und die deutsche Öffentlichkeit." In August 1914. Ein Volk zieht in den Krieg, edited by Berliner Geschichtswerkstatt, 147-55. Berlin: Nishen, 1999.

Janßen, Karl-Heinz, “Tannenberg - ein deutsches Verhängnis.” Zeit, 16 September 1977: 60.

Kabisch, Ernst, "Tannenberg.” In Hans Härlin et al., Schicksalsschlachten der Deutschen Geschichte. Leuthen-Leipzig - Sedan - Tannenberg. 5th ed. Stuttgart: Franckh, 1933, 130-85. 
Kahns, Hans, Das Reichsehrenmal Tannenberg. Königsberg: Gräfe und Unzer, 1937.

Kester, Bernadette, Film Front Weimar: Representations of the First World War in German Films of the Weimar Period (1919-1933). Amsterdam: Amsterdam University Press, 2002.

Ketelsen, Uwe-Karsten, “'Die Jugend von Langemarck'. Ein poetisch-politisches Motiv der Zwischenkriegszeit." In Literatur und Drittes Reich, edited by Uwe-Karsten Ketelsen, 2nd

rev. ed., 172-98. Vierow: SH-Verlag, 1994.

Kitchen, Martin, The Silent Dictatorship: The Politics of the German High Command under Hindenburg and Ludendorff, 1916-1918. New York: Holmes \& Meier, 1976.

Knieß, Gerhard, ed., Der Kreis Neidenburg/Ostpr. im Ersten Weltkrieg und die Tannenberg-Schlacht 1914. Ein literarisches und historisches Mosaik mit zeitgebundenen Berichten aus Büchern, Zeitschriften und Zeitungen aus den Beständen des Heimat-Archivs Knieß. 2 vols. Bremerhaven: Knieß, 1981.

Koch, Werner, and Paul Skriewe, eds., Deutschland muß leben! Sammlung nationaler Gedichte für die Schule des Dritten Reiches, 2nd ed. Halle/S.: Pädagogischer Verlag von Hermann Schroedel, 1934.

Kossert, Andreas, Ostpreußen. Geschichte und Mythos. Munich: Siedler, 2005.

Kossert, Andreas, "Tannenberg 1914 - Ein ostpreußischer Mythos und seine politische Dimension." In Aus der Arbeit der Genealogischen Arbeitsgemeinschaft Neidenburg und Ortelsburg. Festschrift für Bernhard Maxin zum 80. Geburtstag, edited by Martin Jend et al., 43-53. Seeheim-Malchen: GeAGNO, 2008.

Krumeich, Gerd, and Susanne Brandt, eds., Schlachtenmythen. Ereignis - Erzählung - Erinnerung. Cologne: Böhlau, 2003.

Krumeich, Gerd and Antoine Prost, Verdun 1916. Die Schlacht und ihr Mythos aus deutsch-

Kranzëssischer Sicht. Essen: Klartext, 2016 . Hagen Schulze, I: 292-309. Munich: Beck, 2001.

Kürenberg, Joachim von [i.e. Joachim von Reichel], Russlands Weg nach Tannenberg. Berlin: Universitas, 1934 .

Kuratorium für das Reichsehrenmal Tannenberg, ed., Tannenberg. Deutsches Schicksal-Deutsche Aufgabe. Oldenburg: Stalling, 1939.

Lehnert, Detlef "Die geschichtlichen Schattenbilder von „Tannenberg“. Vom Hindenburg-Mythos im Republik, Erste Ersten Weltkrieg zum ersatzmonarchischen Identifikationssymbol in der Weimarer

In Medien und Krieg - Krieg in den Medien, edited by Kurt Imhof and Peter Schulz, 37-71. Zürich: Seismo, 1995.

Leipacher, Karl Otto, Die Russenflut in Ostpreußen. Nach amtlichen Berichten, zuverlässigen Schilderungen und eigenem Erleben. 2 nd ed. Leipzig: Kabitzsch, 1918.

Lezius, Martin, Ludendorff-eine Erledigung! 4th ed. Berlin: Leddihn, 1935.

Lezius, Martin, Tannenberg. Reutlingen: Enßlin \& Laiblin, 1938

Lindenberg, Paul, Das Buch vom Felamarschall Hindenburg. Oldenburg: Stalling, 1920

Lindenberg, Paul, ed., Hindenburg-Denkmal für das deutsche Volk. Eine Ehrengabe zum 75. Geburtstage des Generalfeldmarschalls. 3rd ed. Berlin: Weller, 1924.

Ludendorff, Erich, Meine Kriegserinnerungen 1914-1918. Berlin: Mittler, 1919.

Ludendorff, Erich, Tannenberg. Zum 20. Jahrestag der Schlacht. Munich: Ludendorff, 1934.

Ludendorff, Erich, Tannenberg. Geschichtliche Wahrheit über die Schlacht. Munich: Ludendorff, 1935.

Macleod, Jenny, ed., Defeat and Memory: Cultural Histories of Military Defeat in the Modern Era. Basingstoke: Macmillan, 2008.

Maschke, Erich, "Deutsche Wacht im Osten.” In Tannenberg, edited by Kuratorium, 167-96.

Maser, Werner, Hindenburg. Eine politische Biographie, $2^{\text {nd }}$ ed. Rastatt: Moewig, 1990. 
Mick, Christoph, “'Den Vorvätern zum Ruhm - den Brüdern zur Ermutigung'. Variationen zum Thema

Grunwald/Tannenberg." zeitenblicke, 3/1 (2004): http://zeitenblicke.historicum.net/2004/01/mick/index.html.

Müller, Hans-Harald, Der Krieg und die Schriftsteller. Der Kriegsroman der Weimarer Republik. Stuttgart: Metzler, 1986.

Müller-Eberhart, Waldemar, Kopf und Herz des Weltkrieges. General Ludendorffs Wertung als Deutscher. Leipzig: Kummer, 1935.

Müller-Raabe, Robert, Tannenberg-Weihespiel in 3 Bildern. Unter Benutzung von Motiven vaterländischer Lieder und Gedichte. Berlin: Deutsches Wort, 1921.

Münkler, Herfried, "Politische Mythen und nationale Identität. Vorüberlegungen zu einer Theorie politischer Mythen." In Mythen der Deutschen. Deutsche Befindlichkeiten zwischen Geschichten und Geschichte, edited by Wolfgang Frindte and Harald Pätzolt, 21-27. Opladen: Leske und Budrich, 1994.

Mungenast, Ernst Moritz, Der Held von Tannenberg. Ein Hindenburg-Buch für die Jugend. Stuttgart: Herold, 1934.

Nagornaya, Oxana Sergeevna, “Tannenberg Myth.” In 1914-1918-online. International Encyclopedia of the First World War (2017). https://doi.org/10.15463/ie1418.11206.

Nebelin, Manfred, Ludendorff. Diktator im Ersten Weltkrieg. Munich: Siedler, 2010.

Neumann, Felix, Tannenberg. Ein Schlachtenepos. Berlin: Furche, 1917.

Niemann, Hans, Hindenburgs Siege bei Tannenberg und Angerburg August-September 1914. Das Cannae und Leuthen der Gegenwart. 7th ed. Berlin: Mittler, 1915.

Olivier, Mathieu, "Schlacht bei Tannenberg. Erfolg und Scheitern von Siegesmythen." In Deutschpolnische Erinnerungsorte, edited by Hans-Henning Hahn and Robert Traba, vol. 1: 283-300. Paderborn: Schöningh, 2015.

Oncken, Hermann, "Hindenburg im Lichte der europäischen Geschichte. Zu seinem Hingang am 2. August 1934." In Nation und Geschichte. Reden und Aufsätze 1919-1935, edited by Hermann Oncken, 119-32. Berlin: Grote, 1935.

Pochhammer, Paul, Paul von Hindenburg, der Sieger von Tannenberg. Berlin: Gornitzka, 1915.

Pöhlmann, Markus, "Tod in Masuren. Tannenberg, 23. bis 31. August 1914." In Schlachten der Weltgeschichte. Von Salamis bis Sinai, edited by Stig Förster et al., 279-93. Munich: Beck, 2001.

Prümm, Karl, "Das Erbe der Front. Der antidemokratische Kriegsroman der Weimarer Republik und by seine nationalsozialistische Fortsetzung." In Die deutsche Literatur im Dritten Reich, edited Horst Denkler and Karl Prümm, 138-64. Stuttgart: Reclam, 1976.

Pyta, Wolfram, Hindenburg. Herrschaft zwischen Hohenzollern und Hitler. Munich: Siedler, 2007.

Rauscher, Walter, Hindenburg. Feldmarschall und Reichspräsident. Vienna: Ueberreuter, 1997.

Reichsarchiv, ed. Der Weltkrieg 1914 bis 1918 . Die militarischen Operationen zu Lande, 14 vols. Berlin: Mittler, 1925-44, II: Die Befreiung Ostpreußens (1925).

Reynolds, David, The Long Shadow: The Great War and the Twentieth Century. London: Simon \& Schuster, 2013.

Rohkrämer, Thomas, "Ideenkrieg. Sinnstiftungen des Sinnlosen.” In Erster Weltkrieg. Metzler, Kulturwissenschaftliches Handbuch, edited by Niels Werber et al., 385-409. Stuttgart: 2014.

Rohrscheidt, Walther von, Über Stallupönen und Gumbinnen zum deutschen Vernichtungssieg bei Tannenberg. Braunschweig: Limbach, 1937.

Saldern, Adelheid von, "Mythen, Legenden und Stereotypen." In Mythen in Geschichte und Geschichtsschreibung aus polnischer und deutscher Sicht, edited by Adelheid von Saldern, $13-$ 26. Münster: Lit, 1996.

Schäfer, Theobald von, Tannenberg. Oldenburg: Stalling, 1927. Schäfer, Theobald, Ludendorff. Der Feldherr der Deutschen im Weltkriege. Berlin: Siegismund, 1935. 
Schenk, Frithjof Benjamin, "Tannenberg/Grunwald." In Deutsche Erinnerungsorte, edited by Etienne François and Hagen Schulze, I: 438-54. Munich: Beck, 2001.

Schivelbusch, Wolfgang, Die Kultur der Niederlage. Der amerikanische Süden 1865, Frankreich 1871 ,

Deutschland 1918. Berlin: Fest, 2001.

Schloemp, Felix, ed., Liebe und Trompetenblasen. Lustige Soldaten- und Kriegslieder aus alter und neuester Zeit. Munich: Georg Müller, 1914.

Schnackenburg, Eva, Der Schuss im Walde von Chorzele. Historischer Roman um General Samsonow und die Schlacht bei Tannenberg. Cologne: Schroeder, 1939.

Schneider, Thomas F., ed., Kriegserlebnis und Legendenbildung. Das Bild des ,,modernen “ Krieges in

Literatur, Theater, Photographie und Film. 2 vols. Osnabrück: Universitätsverlag Rasch,

Schneider, Thomas F., and Hans Wagener, eds., Von Richthofen bis Remarque. Deutschsprachige Prosa zum I. Weltkrieg. Amsterdam: Rodopi, 2003.

Schöpflin, George, "The Functions of Myth and a Taxonomy of Myths." Myths and Nationhood, edited by George Schöpflin and Geoffrey Hosking, 19-35. New York: Routledge, 1997.

Schott, Richard, Ostpreussen und sein Hindenburg. Vaterländisches Schauspiel aus der Geschichte der Ostmark. Berlin: Eiko-Film, 1917.

Schulenburg, Dieter von der, Welt um Hindenburg. Hundert Gespräche mit Berufenen. Berlin: Buchund Tiefdruck Gesellschaft, 1935.

Showalter, Dennis E., Tannenberg: Clash of Empires. Hamden, Conn.: Archon Books, 1991.

Skowronnek, Fritz, Hindenburg, der Befreier des deutschen Ostens. Berlin: Meidinger, 1915.

Solzhenitsyn, Alexandr, August 1914 translated by Michael Glenny. London: Bodley Head, 1972.

Stephani, Wolfgang von, Mit Hindenburg bei Tannenberg. Berlin: Eisenschmidt, 1919.

Strecker, Karl, Von Hannibal zu Hindenburg. Studien über Hindenburgs Strategie und ihre Vorläufer. Berlin: Curtius, 1915.

Sweetman, John, Tannenberg 1914. London: Cassell \& Co, 2002.

Szczepanski, Max von, Tannenberg 1914. Leipzig: Teubner, 1929.

Tannenberg 1914-1933. Ein Gedenkbuch für das deutsche Volk. Berlin: Reimar Hobbing, 1933.

Tietz, Jürgen, Das Tannenberg-Nationaldenkmal. Architektur - Geschichte - Kontext. Berlin: Verlag Bauwesen, 1999.

Todman, Dan, The Great War: Myth and Memory. London: Continuum, 2005.

Traba, Robert, "Kriegssyndrom in Ostpreußen. Ein Beitrag zum kollektiven Bewußtsein der Weimarer

Zeit." In Kriegserlebnis, edited by Schneider, I: 399-412.

Treuenfels, Werner, Der Geist von Tannenberg. Vaterländischer Roman. Berlin: Drei Kegel Verlag, 1934.

van Wehrt, Rudolf [i.e. Hans Rudolff Berndorff], Tannenberg. Wie Hindenburg die Russen schlug. Berlin: Ullstein, 1934 .

Vogeler, Adolf, Tannenberg. Vaterländisches Festspiel. Hildesheim: Gerstenberg, 1917.

Vogelsang, Ernst, "Aus der Geschichte des Reichsehrenmals Tannenberg." In Zwischen den

87 , Weltkriegen, edited by Udo Arnold, 2 vols. Lüneburg: Nordostdeutsches Kulturwerk, 1986-

II: $73-122$.

Walter-Schomburg, Kurt Leo, ed., Die Treue ist das Mark der Ehre. Von München bis Tannenberg. Berlin: Tempelkunst-Verlag, 1934.

Watson, Alexander, “Unheard-of Brutality": Russian Atrocities against Civilians in East Prussia, 1914-1915.' The Journal of Modern History, 86 (December 2014): 780-825.

Weinrich, Arndt, "Kult der Jugend - Kult des Opfers. Der Langemarck-Mythos in der Zwischenkriegszeit." Historical Social Research, 34 (2009): 319-30. 
Werminghoff, Albert, Die Schlacht bei Tannenberg in den Jahren 1410 und 1914. Berlin:

Siegismund,

1918.

Werth, German, Verdun. Die Schlacht und der Mythos. Bergisch-Gladbach: Lübbe, 1979.

Wichert, Ernst, Tannenberg. Zwei Schlachten um den deutschen Osten. Frankfurt/M.: Diesterweg, 1939.

Winter, Jay, Sites of Memory, Sites of Mourning: The Great War in European Cultural History. Cambridge: Cambridge University Press, 1995.

Winter, Jay, ed., The Cambridge History of the First World War, 3 vols. Cambridge: Cambridge University Press, 2014.

Wippermann, Wolfgang, Der Ordensstaat als Ideologie. Das Bild des Deutschen Ordens in der deutschen Geschichtsschreibung und Publizistik. Berlin: Colloquium-Verlag, 1979.

Wolff, Theodor, Vollendete Tatsachen 1914-1917. Berlin: Kronen-Verlag, 1918.

Ziemann, Benjamin, "Die Erinnerung an den Ersten Weltkrieg in den Milieukulturen der Weimarer Republik." In Kriegserlebnis, edited by Schneider, I: 249-70.

Zimmermann, John, "Von den operativen und erinnerungsgeschichtlichen Dimensionen eines Raumes.

Die Schlacht von Tannenberg 1914 als Paradebeispiel räumlicher Inszenierung." Militärgeschichtliche Zeitschrift, 73 (2014): 349-65.

Zimmermann, John, "Die Schlacht von Tannenberg 1914. Ein großer deutscher Sieg und eine strategische Niederlage." In Die Mittelmächte und der Erste Weltkrieg, edited by M. Christian Ortner and Hans-Hubertus Mack, 116-41. Vienna: Verlag Militaria, 2016. 